\title{
PERANAN GURU PPKn DALAM MENGIMPLEMENTASIKAN PENDIDIKAN KARAKTER PADA SISWA SMAN 1 KOTA TERNATE
}

\author{
Jainudin Abdullah \\ Dosen Prodi Pendidikan Pancasila dan Kewarganegaraan, FKIP Universitas Khairun, Jl. Bandara Baabullah Akehuda Ternate \\ Utara, 97728, Indonesia
}

Author Correspondence: jainudin_abdullah@yahoo.com

$\begin{array}{ll}\text { Diterima } & : 20-09-2018 \\ \text { Direvisi } & : 30-10-2018\end{array}$

Dipublikasi : :05-11-2018

\begin{abstract}
The aims of this research were (1) the role of civics teachers in shaping the character of students SMA N 1 Kota Ternate, (2) Some obstacles which were faced by civics teachers in shaping the character of students SMA N 1 Kota Ternate. The research method was qualitative descriptive by using descriptive qualitative approach. In this research, it also used quantitative approach as supplement. The strategy of research used was a single stuck strategy. Data sources were from informants, places, events, and documents The method used for data collection are interviews, observation and documentation, while data analysis using interactive data analysis by Miles and Huberman (1992). The results showed that the character-based learning of civics in Public Senior High School SMAN 1 city Ternate good lesson plan, onlyteachers are still a little difficulty in setting the values of character and developmentof teaching materials, but mis condition can still be overcome. Character-based learning implement ation is in accordance with the learning stage of cognitive development is divided into three phases, exploration, elaboration and confirmation in the opinion of teachers, learners, parents of learners and stakeholders that the characters that have been en trenched values are religious values and the value of discipline.
\end{abstract}

Keywords: Teachers, character, Civics, and Students SMA N 1 City Ternate

Abstrak. Tujuan penelitian ini adalah untuk mengetahui: 1). Peran guru PPKn dalam membentuk karakter siswa SMAN I Kota Ternate, 2) Kendala yang dihadapi guru PPKn dalam membentuk karakter siswa SMAN I Kota Ternate. Jenis penelitian ini adalah penelitian lapangan atau field research dimana peneliti terjun langsung ke lapangan untuk memperoleh data dan informasi terkait dengan penelitian yang dilakukan. Penelitian ini disajikan dalam bentuk deskriptif dengan tujuan untuk menggambarkan suatu proses yang terjadi di lapangan. Sedangkan pendekatan yang dilakukan adalah pendekatan kualitatif. Teknik pengumpulan data yang digunakan: observasi, wawancara, dan dokumentasi. Sedangkan teknik analisis datanya menggunakan Model Miles and Huberman, yang terdiri dari: reduksi data (data reduction), penyajian data (data display) dan verifikasi (conclusion drawing). Hasil penelitian menunjukkan bahwa pembelajaran PKn berbasis karakter di SMA N 1 Kota Ternate perencanaan pembelajaran baik, hanya guru masih sedikit kesulitan dalam menetapkan nilai-nilai karakter dan pengembangan bahan ajar tetapi kondisi seperti ini masih bisa diatasi. Pelaksanaan pembelajaran berbasis karakter sudah sesuai dengan tahap perkembangan kognitif dengan pembelajaran dibagi dalam tiga tahapan, eksplorasi, elaborasi dan Konfirmasi menurut pendapat guru, peserta didik, orang tua peserta didik dan stakeholders bahwa nilai karakter yang sudah membudaya adalah nilai religius dan nilai disiplin.

Kata Kunci: Guru, Karakter, Pendidikan Kewarganegaraan, Siswa SMA N 1 Kota Ternate

\section{PENDAHULUAN}

Pendidikan adalah suatu usaha atau kegiatan yang dijalankan dengan sengaja, teratur dan berencana dengan maksud mengubah atau mengembangkan perilaku yang diinginkan. Membangun peradaban sebuah bangsa pada hakikatnya adalah pengembangan watak dan karakter manusia unggul dari sisi intelektual, spiritual, emosional, dan fisikal yang dilandasi oleh fitrah kemanusiaan. Fitrah adalah titik tolak kemuliaan manusia, baik sebagai bawaan seseorang sejak lahir atau sebagai hasil proses pendidikan (Abdul Latief, 2016). Solusi yang ditawarkan di dunia pendidikan adalah pendidikan karakter untuk memperbaiki moral anak bangsa yang kian merosot. Pendidikan karakter ditujukan untuk 
menanamkan nilai-nilai moral kepada peserta didik agar peserta didik dapat menginternalisasikan nilainilai tersebut ke dalam kehidupan sehari-harinya. Pendidikan karakter diharapkan dapat memperbaiki moral bangsa yang bisa dikatakan sudah diambang kebobrokan, khususnya moral para pelajar. Implementasi pendidikan karakter dalam pembelajaran yang dimaksud disini adalah pada mata pelajaran yang ada di sekolah. Implementasi pendidikan karakter dalam pembelajaran harus dilakukan dengan strategi yang matang dengan melihat kondisi dan kemampuan siswa serta lingkungan sekitarnya.

Menurut Daryanto (2013), pendidikan karakter disebutkan sebagai sebagai pendidikan nilai, pendidikan budi pekerti, pendidikan moral, pendidikan watak, yang bertujuan mengembangkan kemampuan peserta didik untuk memberikan keputusan baik baik-buruk, memelihara apa yang baik dan mewujudkan kebaikan itu dalam kehidupan sehari-hari dengan sepenuh hati. Pendidikan karakter yang baik harus melibatkan bukan saja aspek 'pengetahuan yang baik' akan tetapi juga merasakan dengan baik atau loving good (Daryanto, 2013: 42). Pendidikan karakter dapat diimplemetasikan melalui beberapa strategi dan pendekatan yang meliputi; (1) pengintegrasian nilai dan etika pada mata pelajaran; (2) internalisasi nilai positif yang di tanamkan oleh semua warga sekolah (kepala sekolah, guru, dan orang tua); (3) pembiasaan dan latihan; (4) pemberian contoh dan teladan; (5) penciptaan suasana berkarakter di sekolah; dan (6) pembudayaan. Sebagai upaya untuk meningkatkan kesesuaian dan mutu pendidikan karakter, Kementerian Pendidikan Nasional mengembangkan Grand Design pendidikan karakter untuk setiap jalur, jenjang, dan jenis satuan pendidikan. Integrasi pendidikan karakter dalam proses pembelajaran dilaksanakan dengan berpedoman pada silabus, RPP, dan buku ajar yang berwawasan pendidikan karakter. Nilai-nilai karakter yang terintegrasi dalam mata pelajaran PKn adalah meliputi; nasionalis, patuh pada aturan sosial, demokratis, jujur, menghargai keragaman, sadar akan hak dan kewajiban diri dan orang lain.

Pendidikan kewarganegaraan merupakan mata pelajaran yang sarat isi dengan nilai-nilai pancasila untuk membentuk kepribadian. Pendidikan kewarganegaraan tidak cukup hanya sampai pada penghapalan, melainkan pendidikan kewarganegaraan diterapkan dalam kehidupan sehari-hari peserta didik dalam bentuk perbuatan, nilai-nilai yang terkandung dalam pancasila bukan untuk dihapal melainkan untuk dipraktekkan dalam kehidupan nyata. Oleh karena itu, pembelajaran pendidikan kewarganegaraan perlu mengutamakan perilaku (Abdul Latief, 2016). Pendidikan Kewarganegaraan bertujuan antara lain yaitu menanamkan nilai-nilai pancasila dan pola berpikir yang sesuai dengan Pancasila dan Undang-Undang Dasar 1945, sehingga tumbuh keyakinan motivasi dan kehendak untuk senantiasa sesuai dengan nilai-nilai atau norma Pancasila dan Undang-Undang Dasar 1945. Di samping itu orientasi bidang studi tersebut adalah membentuk warga Negara yang baik dan memiliki akhlak mulia. Hal ini dapat dilihat dari dimensi nilai-nilai kewarganegaraan (civics value) yang mencakup penguasaan atas nilai religius, norma dan moral luhur dan mengamalkan ajaran-ajaran tersebut dalam kehidupan sehari-hari.

PKn sebagai salah satu mata pelajaran yang memiliki muatan dalam pendidikan moral dan nasioalisme, merupakan sebuah mata pelajaran yang wajib mengambil bagian dalam proses pendidikan karakter melalui peran guru PKn. Dengan menerapkan metode pengajaran yang tepat dan didukung oleh semua jajaran personel dilembaga pendidikan tersebut, maka guru PKn dapat mengambil inisiatif untuk menjadi pendorong berlangsungnya program pembelajaran karakter tersebut. Sebagai output dari pembelajaran PKn ini akan diperoleh generasi yang memiliki sumberdaya manusia yang benar-benar berkualitas sesuai dengan tujuan pendidikan nasional. Itulah sebabnya pendidikan karakter sangat penting. Pendidikan karakter harus diimplementasikan kemudian diintegrasikan dalam kehidupan sekolah, baik dalam konteks pembelajaran di dalam kelas maupun di luar kelas.

Pendidikan karakter di sekolah tidak berdiri sendiri, tetapi dilaksanakan secara terintegrasi ke dalam setiap mata pelajaran, khususnya mata pelajaran PKn. Adapun nilai-nilai karakter yang terintegrasi dalam mata pelajaran PKn meliputi; nasionalis, patuh pada aturan sosial, demokratis, jujur, menghargai keragaman, sadar akan hak dan kewajiban diri dan orang lain. Selain itu, silabus dan rencana pelaksanaan pembelajaran, serta buku ajar yang digunakan guru untuk mengajar harus 
memuat/berwawasan pendidikan karakter, yaitu dengan mengadaptasi pendidikan karakter sesuai dengan materi yang akan diajarkan.

Mengimplementasikan nilai-nilai karakter pada pembelajaran bertujuan untuk menanamkan nilai-nilai pada siswa akan pentingnya pendidikan karakter, sehingga mereka mampu menginternalisasikan nilainilai tersebut tingkah laku sehari-hari. Berdasarkan latar belakang masalah diatas, maka pertanyaan penelitian yang diajukan dalam penelitian ini adalah bagaimana peranan guru PPKn dalam mengimplementasikan pendidikan karakter pada peserta didik dan kendala-kendala apa sajakah yang dialami oleh guru PPKn dalam mengimplementasikan pendidikan karakter di SMAN 1 Kota Ternate?

\section{METODE PENELITIAN}

Penelitian ini adalah penelitian lapangan atau field research yaitu peneliti langsung ke lapangan untuk memperoleh data dan informasi terkait dengan penelitian yang dilakukan. Penelitian ini disajikan dalam bentuk deskriptif dengan tujuan untuk menggambarkan bagaimana implementasi pendidikan karakter pada peserta didik SMAN 1 Kota Ternate. Sedangkan pendekatan yang dilakukan adalah pendekatan kualitatif.

Penelitian ini dilaksanakan di SMAN 1 Kota Ternate pada April hingga Agustus 2018. Adapun yang menjadi subjek penelitian ini diantaranya: Kepala Sekolah, Wakil Kepala Sekolah bidang Kurikulum, Guru PKn dan peserta didik SMAN 1 Kota Ternate. Penentuan subjek penelitian dilakukan dengan purposive, yaitu berdasarkan tujuan penelitian.

\section{Teknik Pengumpulan dan Analisis Data}

Dalam penelitian ini, penulis menggunakan teknik pengumpulan data diantaranya: (1) Pengamatan atau observasi, yakni pengamatan secara langsung terhadap objek atau sasaran yang berkaitan dengan penelitian ini guna memperoleh data awal. Observasi diartikan pengamatan dan pencatatan secara sistematis terhadap gejala yang tampak pada objek penelitian; (2) Wawancara atau interview, yakni dengan menggunakan instrumen pedoman wawancara kepada informan (peserta didik SMAN 1 Kota Ternate) untuk memperoleh data-data penelitian; (3) Dokumentasi, yakni alat yang dibuat peneliti untuk mendapatkan gambaran pada saat penelitian berlangsung dan sebagai pembuktian penelitian serta pelengkap data untuk mendukung data peneliti sehingga peneliti memperoleh hasil penelitian dengan baik dan ilmiah.

Sementara teknik analisis data yang peneliti lakukan yaitu dengan menggunakan tiga komponen analisis data yaitu, (1) Reduksi data (data reduction). Kegiatan ini dilakukan oleh peneliti pada alur reduksi data adalah melakukan pemilihan, membuat ringkasan, pemusatan perhatian pada penyederhanaan, dan transformasi data kasar yang muncul dari catatan catatan tertulis di lapangan; (2) Penyajian data (data display). Selanjutnya peneliti melakukan kegiatan pengumpulan informasi yang telah tersusun dari hasil reduksi data. Menyajikan data dalam bentuk teks yang bersifat naratif, gambar dan tabel; (3) Menarik kesimpulan/verifikasi (conclusion/ drawing verification). Pada alur akhir analisis data ini adalah menarik kesimpulan dan verifikasi. Kesimpulan yang dikemukakan merupakan temuan akhir dan permanen yang dapat menjawab permasalahan penelitian.

\section{PEMBAHASAN HASIL PENELITIAN}

\section{A. Implementasi Pendidikan Karakter di SMA N 1 Kota Ternate}

Berdasarkan hasil penelitian yang dilakukan oleh peneliti di SMA N 1 Kota Ternate, melalui observasi, wawancara dan dokumentasi yang dilakukan terhadap guru PKn mengenai implementasi pendidikan karakter. Hasil penelitian menjelaskan tentang peran guru dalam pelaksanaan pendidikan karakter meliputi guru sebagai teladan, guru sebagai pengajar, guru sebagai pembimbing, guru sebagai inspirator, guru sebagai motivator, guru sebagai dinamisator, dan guru sebagai evaluator. Peran guru dalam 
pendidikan karakter telihat pada internalisasi nilai-nilai karakter meliputi; (1) nilai religius; (2) nilai tanggung jawab; (3) nilai disiplin; dan (4) nilai peduli sosial.

Nilai-nilai karakter yang ditetapkan Depdiknas meliputi 18 karakter, yakni; (1) Religius, yakni sikap dan perilaku yang patuh dalam melaksanakan ajaran agama yang dianutnya, toleran terhadap pelaksanaan ibadah agama lain, dan hidup rukun dengan pemeluk agama lain; (2) Jujur yakni perilaku yang didasarkan pada upaya menjadikan dirinya sebagai orang yang selalu dapat dipercaya dalam perkataan, tindakan, dan pekerjaan; (3) Toleransi, yakni sikap dan tindakan yang menghargai perbedaan agama, suku, etnis, pendapat, sikap, dan tindakan orang lain yang berbeda dari dirinya; (4) Disiplin, yakni tindakan yang menunjukkan perilaku tertib dan patuh pada berbagai ketentuan dan peraturan; (5) Kerja keras, merupakan tindakan yang menunjukkan perilaku tertib dan patuh pada berbagai ketentuan dan peraturan; (6) Kreatif, yakni berpikir dan melakukan sesuatu untuk menghasilkan cara atau hasil baru dari sesuatu yang telah dimiliki; (7) Mandiri, yakni sikap dan perilaku yang tidak mudah tergantung pada orang lain dalam menyelesaikan tugas-tugas; (8) Demokratis, yaitu cara berpikir, bersikap, dan bertindak yang menilai sama hak dan kewajiban dirinya dan orang lain; (9) Rasa ingin tahu, yakni sikap dan tindakan yang selalu berupaya untuk mengetahui lebih mendalam dan meluas dari sesuatu yang dipelajarinya, dilihat, dan didengar; (10) Semangat kebangsaan, yaitu cara berpikir, bertindak, dan berwawasan yang menempatkan kepentingan bangsa dan negara di atas kepentingan diri dan kelompoknya; (11) Cinta tanah air, yaitu cara berpikir, bertindak, dan berwawasan yang menempatkan kepentingan bangsa dan negara di atas kepentingan diri dan kelompoknya; (12) Menghargai prestasi, yaitu sikap dan tindakan yang mendorong dirinya untuk menghasilkan sesuatu yang berguna bagi masyarakat, dan mengakui, serta menghormati keberhasilan orang lain; (13) Bersahabat/Komunikatif yakni, sikap dan tindakan yang mendorong dirinya untuk menghasilkan sesuatu yang berguna bagi masyarakat, dan mengakui, serta menghormati keberhasilan orang lain; (14) Cinta damai, artinya sikap dan tindakan yang mendorong dirinya untuk menghasilkan sesuatu yang berguna bagi masyarakat, dan mengakui, serta menghormati keberhasilan orang lain; (15) Gemar membaca, yakni kebiasaan menyediakan waktu untuk membaca berbagai bacaan yang memberikan kebajikan bagi dirinya; (16) Peduli lingkungan berarti sikap dan tindakan yang selalu berupaya mencegah kerusakan pada lingkungan alam di sekitarnya, dan mengembangkan upaya-upaya untuk memperbaiki kerusakan alam yang sudah terjadi; (17) Peduli sosial bermakna sikap dan tindakan yang selalu ingin memberi bantuan pada orang lain dan masyarakat yang membutuhkan; dan (18) Tanggung jawab yaitu sikap dan perilaku seseorang untuk melaksanakan tugas dan kewajibannya, yang seharusnya dia lakukan, terhadap diri sendiri, masyarakat, lingkungan (alam, sosial dan budaya), negara dan Tuhan Yang Maha Esa.

Dari hasil observasi ke-18 nilai karakter tersebut dapat diimplementasikan dengan baik di SMA N 1 Kota Ternate. Untuk membentuk karakter kedisiplinan peserta didik yaitu guru sebagai tenaga pendidik harus memiliki karakteristik kepribadian yang sangat berpengaruh terhadap keberhasilan pengembangan sumber daya manusia. Kepribadian yang manfaat dari sosok seorang guru akan memberikan teladanan yang baik terhadap anak didik maupun masyarakat. Sehingga guru akan tampil sebagai sosok yang patut (ditaati nasehat/ perintahnya) dan ditiru (contoh sikap dan perilakunya). Sedangkan kepala sekolah melakukan implementasi pendidikan karakter melalui format-format yang dimasukkan dalam kompetensi belajar para guru, dan juga banyak melaksanakan kegiatan-kegiatan yang berbasis pada pengembangan potensi para siswa seperti kepramukaan, PMR, OSIS dan kegiatan lainnya. Namun tidak dapat dipungkiri bahwa di dalam pelaksanaannya masih terdapat berbagai macam kendala-kendala yang dihadapi seperti letak geografis sekolah yang berjauhan dengan tempat tinggal siswa, sehingga mngakibatkan para siswa sering dan bahkan selalu setiap hari datang terlambat.

Mata pelajaran Pendidikan Kewarganegaraan (PKn) merupakan pendidikan politik yang fokus materinya berupa peranan warga negara dalam kehidupan bernegara yang kesemuanya itu diproses dalam rangka untuk membina peranan tersebut sesuai dengan ketentuan Pancasila dan UUD 1945 agar menjadi warga negara yang dapat diandalkan oleh bangsa dan negara. Pendidikan Kewarganegaraan lebih merupakan bentuk pengajaran politik atau pendidikan politik. Sebagai pendidikan politik berarti 
fokusnya lebih menekankan bagaimana membina warga negara yang lebih baik (memiliki kesadaran politik dan hukum) lewat suatu proses belajar mengajar (Cholisin, 2004:11). Selain itu, Pendidikan Kewarganegaraan adalah sebagai wahana untuk mengembangkan kemampuan, watak dan karakter warga negara yang demokratis dan bertanggung jawab.

Berdasarkan hasil wawancara yang dilakukan oleh peneliti bahwa ada beberapa aitem atau tahap peran guru dalam upaya pembentukan karakter kedisiplinan yaitu bahwa implementasi pendidikan karakter di SMA N 1 Kota Ternate sudah terlaksana sejak tahun 2011, dan melibatkan semua guru dalam melaksanakan pendidikan karakter pada siswa, baik melalui pada saat proses pembelajaran maupun di luar pembelajaran, khususnya pada mata pelajaran PKn dan agama proses pembentukan karakter siswa lebih diperhatikan dimana pada mata pelajaran PKn para siswa diberikan pemahaman mengenai cinta tanah air, toleransi, etika, moral, perilaku yang baik dan benar, saling menghargai dan menghormati.

Kegiatan-kegiatan yang dimaksudkan dalam pendidikan karakter religius di SMA N 1 Kota Ternate adalah pada hari senin sampai kamis peserta didik di ajarkan sebelum memasuki kelas semua peserta didik diharuskan berdoa bersama di lapangan upacara, sebelum pulang peserta didik diharuskan melakukan sholat dzuhur bersama. Pulang sekolah dan pada hari jumat peserta didik diberikan kultum atau ceramah oleh Ustad atau guru pendidikan agama yang berada di SMA N 1 Kota Ternate. Kemudian pada hari sabtu kegiatan dilanjutkan seperti pada hari-hari sebelumnya. Selanjutnya kedisplinan guru, misalnya keterlambatan guru pada upacara dan pada jam mengajar. Kemudian keterampilan guru antara lain kegiatan membuat salawaku pada jam olahraga, dan latihan mersing band untuk melatih keterampilan peserta didik.

Dari hasil pengamatan di SMA N 1 Kota Ternate para guru PKn memberikan pembinaan dan mental siswa dengan cara menasehati dan membiasakan kepada seperti masalah adat, menjaga kebersihan sekolah, selalu taat kepada peraturan sekolah ini sejalan dengan tugas dan tanggung jawab seorang guru diantaranya adalah menciptakan suasana atau iklim proses pembelajaran yang dapat memotivasi siswa untuk senantiasa belajar dengan baik dan semangat. Tugas seorang guru itu mencakup beberapa hal, salah satunya bahwa guru memiliki tugas yang beragam yang berimplementasi dalam bentuk pengabdian. Dengan demikian, tugas dan tanggungjawab guru tidak dapat dibatasi oleh ruang dan waktu. Oleh karena itu, keterbatasan jam dan kelas untuk mendidik, karena proses belajar tidak hanya dilakukan di sekolah namun sekurang-kurangnya dapat membentuk landasan yang berarti untuk bekal siswa selanjutnya.

\section{B. Kendala-Kendala Implementasi Pendidikan Karakter di SMA N 1 Kota Ternate}

Berdasarkan hasil observasi, implementasi pendidikan karakter pada peserta didik di SMAN 1 Kota Ternate masih sangat kurang. Kendala yang dihadapi para guru dalam mengimplementasikan pendidikan karakter, diantaranya; (a) Letak Geografis Sekolah yang jauh dari tempat tinggal para siswa, sehingga dapat menghambat proses pelaksanaan kegiatan-kegiatan belajar dan ekstrakurikuler; (b) Tingkat pendidikan orang tua murid masih sangat rendah sehingga dapat menghambat penerapan pendidikan karakter, sebab para orang tua hanya beriskap diam dan menyerahkan pendidikan sepenuhnya kepada para guru dan mereka tidak menyadari bahwa peran orang tua sangat membantu tercapainya tujuan tersebut; dan (c) Kurangnya pengetahuan dan pemahaman siswa tentang pendidikan karakter, karena dengan pengetahuan para peserta didik sangat mendukung tercapainya pendidikan karakter yang berikan pada setiap saat proses pembelajaran, karena sulit menerapkan bahkan memberikan pemahaman kepada siswa jika mereka sendiri tidak bisa memahami apa itu pendidikan karakter, tujuannya, dan apa manfaatnya bagi mereka, baik dilingkungan sekolah maupun lingkungan masyarakat.

Di samping itu, kendala dalam implementasi pendidikan karakter pada proses pembelajaran PPKn ialah bersumber dari keadaan siswa yang kurang siap dan kurang paham akan pesan pendidikan karakter yang akan disampaikan. Dengan demikian, solusi yang ada ialah mempersiapkan siswa terlebih dahulu sebelum memulai kegiatan pembelajaran, dengan menyampaikan standar kompetensi dan kompetensi 
dasar dari sebuah submateri serta menyampaikan pesan karakter yang terkandung dalam materi yang akan diajarkan. Menurut Sudjana (2002:15), menyebutkan tugas dan tanggung jawab guru, yaitu: (a) Guru sebagai pengajar, (b) Guru sebagai pembimbing, dan (c) guru sebagai administrator. Ketiga tugas guru di atas merupakan tugas pokok profesi guru. Dimana guru sebagai pengajar lebih menekankan kepada tugas dalam merencanakan dan melaksanakan pengajaran. Guru sebagai pembimbing memberi tekanan kepada tugas, memberikan bantuan kepada siswa dalam pemecahan masalah yang dihadapinya. Sedangkan guru sebagai administrator kelas pada hakikatnya merupakan jalinan antara pengajaran dan ketatalaksanaan pada umumnya. Tanggung jawab meningkatkan peranan profesional guru. Bertolak dari tanggung jawab guru yang telah dikemukakan di atas maka dengan demikian guru sangat perlu meningkatkan peranan dan kemampuan profesionalnya. Tanpa adanya kecakapan yang maksimal yang dimiliki oleh guru maka kiranya sulit bagi guru tersebut mengemban dan melaksanakan tanggung jawabnya dengan cara yang sebaik-baiknya.

Dari hasil wawancara dengan sejumlah guru PPKn dapat ditemukan bahwa, Pertama, penerapan atau implementasi pendidikan karakter pada siswa tidak terlepas dari peranan guru, karena guru pada hakekatnya sebagai pendidik, pengajar, penasehat, teladan, dan motivator bagi para peserta didik. Kedua, meskipun implemenmtasi pendidikan karakter di SMA N I Kota Ternate dari tahun 2009 hingga saat ini menunjukan peningkatan yang sangat baik dari pada tahun-tahun sebelum, namun para guru dan kepala sekolah terus mengupayakan agar supaya hal tersebut dapat didorong oleh orang tua siswa. Ketiga, Satuan pendidikan sebenarnya selama ini sudah mengembangkan dan melaksanakan nilai-nilai pembentuk karakter melalui program operasional satuan pendidikan masing-masing. Hal ini merupakan prakondisi pendidikan karakter pada satuan pendidikan yang untuk selanjutnya pada saat ini diperkuat dengan 18 nilai karakter. Pelaksanaan proses pembelajaran dengan metode belajar yang bervariasi serta peran guru sebagai fasilitator dan teladan yang baik, maka akan menimbulkan rasa semangat bagi siswa untuk mengikuti pembelajaran sampai akhir dan pesan pendidikan karakter dalam materi pun dapat diserap siswa dengan baik. Dengan demikian, tugas dan tanggungjawab guru tidak dapat dibatasi oleh ruang dan waktu. Oleh karena itu, keterbatasan jam dan kelas untuk mendidik. Karena proses belajar tidak hanya dilakukan di sekolah namun sekurang-kurangnya dapat membentuk landasan yang berarti untuk bekal siswa selanjutnya.

Tugas guru sebagai profesi meliputi mendidik, mengajar dan melatih. Mendidik berarti meneruskan dan mengembangkan nilai-nilai hidup dan kehidupan. Mengajar berarti meneruskan dan mengembangkan ilmu pengetahuan dan teknologi. Sedangkan melatih berarti mengembangkan keterampilan-keterampilan pada peserta didik. Menurut Wijaya dkk (1994:9), menyebutkan beberapa tanggung jawab yang memerlukan sejumlah kemampuan yang lebih kusus dari seorang guru, yaitu; (1) Tanggung jawab moral adalah setiap guru harus memiliki kemampuan menghayati perilaku dan etika yang sesuai dengan moral Pancasila dan mengamalkannya dalam kehidupan sehari-hari; (2) Tanggung jawab dalam bidang pendidikan di sekolah adalah setiap guru harus menguasai cara belajar-mengajar yang efektif, mampu membuat satuan pelajaran, mampu dan memahami kurikulum dengan baik, mampu mengajar dikelas, mampu menjadi model bagi siswa, mampu memberikan nasihat, menguasai teknik-teknik pemberian bimbingan dan layanan, mampu membuat dan melaksanakan evaluasi dan lain-lain; (3) Tanggung jawab guru dalam bidang kemasyarakatan adalah turut serta menyukseskan pembangunan dalam bidang kemasyarakatan, untuk itu guru harus mampu membimbing, mengabdi dan melayani masyarakat; (4) Tanggung jawab guru dalam bidang keilmuan, yaitu guru selaku keilmuan bertanggung jawab dan turut serta memajukan ilmu, terutama ilmu yang telah menjadi spesialisasinya dengan melaksanakan penelitian dan pengembangan.

Dari hasil pengamatan dan wawancara, bahwa implementasi pendidikan karakter pada peserta didik SMA N 1 Kota Ternate begitu pentingnya pendidikan karakter religius namun demikian masih terdapat beberapa kendala diantaranya:

\section{Faktor Ekonomi}


Dalam proses perkembanganya, betapapun ukuranya bervariasi, seorang anak pasti memerlukan biaya. Biaya untuk makan dan minum di rumah, tetapi juga untuk membeli alat-alat dan perlengkapan sekolah.

\section{Faktor lingkungan}

Faktor ini juga dapat disebut dengan faktor luar. Dalam lingkungan, anak diajarkan tentang nilai-nilai budaya setempat. Dengan faktor tertentu dan faktor lingkungan tertentu pula maka akan menghasilkan pola pertumbuhan dan perkembangan tertentu pula. Setiap individu lahir dengan hereditas tertentu. Namun individu itu tumbuh dan berkembang tidak lepas dari lingkungannya baik lingkungan fisik, lingkungan psikologi, maupun lingkungan sosial. Setiap pertumbuhan dan perkembangan yang kompleks merupakan hasil interaksi dari hereditas dan lingkungan. Hubungan antara faktor hereditas dan lingkungan, faktor hereditas beroperasi dengan cara yang berbeda-beda menurut kondisi dan keadaan lingkungan yang berbeda-beda pula. Selain dengan interaksi hubungan antara hereditas dan lingkungan dapat pula digambarkan sebagai Additive Contribution (sama-sama menyumbang bagi pertumbuhan dan perkembangan fisiologi dan juga tingkah laku. Lingkungan sebagai kondisi atau pengalaman-pengalaman interaksional yang memungkinkan berlangsungnya proses perkembangan. Misalnya, di dalam keluarga, setiap anak mempunyai karakter dan pengalaman yang berbeda-beda. Tergantung dari perlakuan orang tua kepada setiap anak-anaknya, dan pergaulan dari masing-masing anak.

\section{Lingkungan fisik}

Faktor-faktor yang termasuk lingkungan fisik adalah cuaca, keadaan udara, ruangan, cahaya, kesehatan lingkungan, dan waktu belajar yang digunakan pesera didik. Faktor-faktor ini dipandang turut menentukan tingkat keberhasilan belajar peserta didik. Mengenai waktu yang disenangi untuk belajar seperti pagi atau sore hari, seorang ahli bernama J. Biggers (1980) berpendapat bahwa belajar pagi hari lebih efektif daripada belajar pada waktu-waktu lainnya. Namun, menurut penelitian beberapa ahli Learning Style (gaya belajar), hasil belajar itu tidak tergantung pada waktu secara mutlak, tetapi bergantung pada pilihan waktu yang cocok dengan kesiapsiagaan peserta didik (Dunn, dkk., 1986).

Menurut V. Campbell dan R. Obligasi (1982) menyatakan ada beberapa faktor yang berpengaruh dalam pembentukan karakter seseorang yaitu; faktor keturunan, pengalaman masa kanak-kanak, pemodelan oleh orang dewasa atau orang yang lebih tua, pengaruh lingkungan sebaya, lingkungan fisik dan sosial, subtansi materi di sekolah atau lembaga pendidikan lain, dan media massa.

\section{Faktor Religius}

Sebagai contoh seorang anak pemudah agama, sudah pasti akan berbeda dengan anak lain yang tidak menjadi, yang sekedar terhitung orang beragama, lebih-lebih yang memang tidak beragama sama sekali, ini adalah soal perkembangan pula, menyangkut proses terbentuknya perilaku seorang anak dengan agama sebagai faktor penting yang mempengaruhinya.

Selain itu, terdapat kendala-kendala dalam pembinaan karakter, seperti pergaulan bebas yang dilakukan peserta didik di luar sekolah. Karena dengan adanya pergaulan bebas dapat mempengaruhi sikap dan tingkah laku peserta didik, yang tadinya peserta didik memiliki sikap dan tingkah laku yang baik tiba-tiba bisa berubah yang diakibatkan dari pergaulan bebas. Seiring dengan perkembangan zaman peserta didik dengan adanya teknologi yang pesat seperti handphone yang memiliki jaringan internet sehingga peserta didik salah memanfaatkannya, seperti mengakses gambar porno, dan hal-hal negatif lainnya, serta kurangnya pendidikan agama sehingga bisa berdampak pada perilaku peserta didik.

Terkait dengan permasalahan ini mengharuskan pada guru PKn SMA N I Kota Ternate untuk mencari alternatif dalam rangka implementasi pendidikan karakter pada peserta didik demi tercapainya tujuan pendidikan karakter. Juliana (2011) menyatakan bahwa pendidikan karakter dimulai sejak usia dini dan pihak yang paling bertanggung jawab untuk mendidik, mengasuh dan membesarkan anak-anak menjadi generasi yang tangguh adalah orang tua. Orang tua adalah pihak yang paling dekat dengan anak 
sehingga kebiasaan dan segala tingkah laku yang terbentuk dalam keluarga menjadi contoh dan dengan mudah ditiru anak (Wibowo, 2012: 120).

\section{KESIMPULAN}

Dari uraian yang dikemukan diatas dapat di simpulkan bahwa penerapan atau implementasi pendidikan karakter pada siswa di SMA I Kota Ternate tidak terlepas dari peranan guru PKn, hal ini disebabkan karena guru yang memfasilitasi kemampuan, watak/karakter, pengetahuan peserta didik karena guru pada hakekatnya sebagai pendidik, pengajar, penasehat, teladan, dan motivator bagi para peserta didik. Oleh karena itu, guru PKn memiliki peranan yang sangat besar dalam membimbing, mengarahkan, serta membentuk moral, sikap, dan perilaku siswa menjadi berkarakter demi kemajuan suatu bangsa.

Oleh karena itu, pelaksanaan pendidikan karakter di SMA N 1 Kota Ternate dapat berjalan dengan baik. Hal tersebut dapa dibuktikan dengan; guru memiliki rencana pembelajaran/ RPP dan silabus selama 1 tahun kedepan dan, mengupayakan media pembelajaran dalam setiap penyampaian materi, guru memberikan bimbingan secara individu/langsung dan kelompok, tujuannya untuk mengarahkan siswa ke hal yang positif, Guru selalu memberikan contoh tindakan/perbuatan yang baik agar dapat ditiru oleh siswanya. Seperti sholat berjama'ah, bersalaman, membuang sampah pada tempatnya dan lain sebagainya. Di samping itu perannya sebagai inspirator, secara langsung dituntut untuk memiliki pengetahuan dan wawasan yang luas, menanamkan nilai-nilai karakter berdasarkan keseharian dilingkungan sekolah maupun di rumah. Dalam hal ini, guru sebagai motivator harus dapat membangkitkan belajar siswa, motivasi di lakukan saat awal, pertengahan dan akhir pembelajaran yang bertujuan untuk menilai keberhasilan siswa, dengan cara guru terjun langsung untuk mengawasi dalam setiap kegiatan siswa.

Namun demikian terdapat beberapa kendala yang dihadapi oleh guru mata pelajaran PKn di SMA N I Kota Ternate yaitu jam mengajar guru terlalu banyak, materi yang harus disampaikan tidak sesuai dengan alokasi waktu yang ada, jumlah siswa banyak sehingga guru tidak bisa memantau satu per satu perkembangan karakter siswa, siswa banyak yang bermasalah, dan pihak keluarga kurang memberikan perhatian kepada anaknya. Selain itu, kurangnya pengetahuan dan pemahaman siswa tentang pendidikan karakter, sehingga dapat berpengaruh pada proses pembelajaran mengenai pendidikan karakter. Dan kurangnya kerja sama dari pihak orang tua siswa dalam menanamkan pendidikan karakter, hal ini terjadi karena tingkat pemahaman orang tua siswa masih kurang dan minimnya tingkat pendidikan orang tua siswa masih sangat rendah sehingga pihak sekolah sulit untuk mengimplementasikan pendidikan karakter didalam kehidupan sehari-hari bagi siswa. Khususnya pada pembentukan karakter kedisiplinan para siswa. Terkait dengan permasalahan ini mengharuskan pada guru PKn untuk mencari alternatif dalam rangka implementasi pendidikan karakter pada peserta didik demi tercapainya tujuan pendidikan karakter, lebih dari itu pembangunan karakter tidak lepas juga dari peran orang tua, masyarakat, dan sekolah. Dengan demikian, peran guru serta orang tua menjadi sangat penting, khususnya guru PKn.

\section{DAFTAR PUSTAKA}

A.R. Tilaar. (2008). Manajemen Pendidikan Nasional. Bandung: Remaja Rosdakarya.

Abdul, Latief. (2016). Peran Guru Pendidikan Kewarganegaraan Dalam Pendidikan Karakter Peserta Didik kelas X Di SMK Negeri Paku. Jurnal Pepatuzdu, Vol. 11, No. 1 Mei 2016.

Edward dan Sallis, (2004), Manajemen Kualitas Total Dalam Pendidikan (Total Quality Management in Education). Penerjemah: Kambey Daniel C., Manado: Program Pasca Sarjana Universitas Negeri Manado.

Dedi Supardi dan Fasli Jalal. (2001). Reformasi Pendidikan dalam Konteks Otonomi Daerah, Kerjasama Depdiknas, Bapenas, dan Adicita Karya Nusa.

Depdibud. (1992). Peraturan Pemerintah RI Nomor 38 tahun 1992 Tentang Tenaga Kependidikan. Jakarta: Ditjen Dikdasmen.

Depdibud. (1996). Pedoman Kerja Pelaksanaan Supervisi.Jakarta Ditjen Dikdasmen.

Fadil Yudia Fauzi, Ismail Arianto, Etin Solihatin. 2003. Jurnal PPKn UNJ Online, Volume 1, Nomor 2, Tahun 2003, ISSN, 2337-5205. 
Fajar A Malik. (2005). Holistika Pemikiran Pendidikan. Jakarta: PT. Grafindo Persada.

Sagala, Syaiful. (2010). Manajemen Strategik dalam Peningkatan Mutu Pendidikan. Bandung: Penerbit Alfabeta.

Mulyono, (2009). Manajemen Administrasi Dan Organisasi Pendidikan. Yogyakarta: Ar-Ruzz Media.

Margono, (2011). Metodologi penelitian pendidikan. Jakarta: Rineka Cipta.

Ngalim Purwanto. (2010). Administrasi Dan Supervisi Pendidikan. Bandung: Remaja Rosdakarya.

Sa’ud, Udin Syaefudin dan Abin Syamsuddin Makmun. 2006. Perencanaan Pendidikan Suatu Pendekatan Komprehensif. Bandung: PT Remaja Rosdakarya.

Siagian, Sondang P. (2002). Kiat Meningkatkan Produktivitas Kerja. Jakarta: Rineka Cipta.

Suderadjat, Hari. (2005). Manajemen Peningkatan Mutu Berbasis Sekolah. Bandung: Cipta Cekasa Grafika.

Suharyanto, Hadriyanus dan Agus Heruanto Hadna. (2005). Manajemen Sumber Daya Manusia. Yogyakarta: Media Wacana.

Syafaruddin. (2002). Manajemen Mutu Terpadu dalam Pendidikan, Konsep,Strategi dan Aplikasi. Jakarta: Grasindo. 